\title{
Effect of human feeding on the road mortality of Rhesus Macaques on National Highway - 7 routed along Pench Tiger Reserve, Madhya Pradesh, India
}

\section{A. Pragatheesh}

Research Fellow, Environmental Impact Assessment Cell, Wildlife Institute of India, Chandrabani, Dehradun, Uttarakhand 248001, India

Email: pragatheesh@gmail.com

Date of publication (online): 26 April 2011 Date of publication (print): 26 April 2011 ISSN 0974-7907 (online) | 0974-7893 (print)

Editor: Mewa Singh

\section{Manuscript details:}

Ms \# 02669

Received 06 January 2011

Final received 04 February 2011

Finally accepted 10 February 2011

Citation: Pragatheesh, A. (2011). Effect of human feeding on the road mortality of Rhesus Macaques on National Highway-7 routed along Pench Tiger Reserve, Madhya Pradesh, India. Journal of Threatened Taxa 3(4): 1656-1662.

Copyright: (C) A. Pragatheesh 2011. Creative Commons Attribution 3.0 Unported License. JoTT allows unrestricted use of this article in any medium for non-profit purposes, reproduction and distribution by providing adequate credit to the authors and the source of publication.

Author Details: A. Pragatheesh is a research fellow pursuing doctoral research at the Wildlife Institute of India (WII) on the topic "Assessment of the existing National Highway -7 and its proposed widening on habitat use and movement of wild animals in Pench Tiger Reserve, Madhya Pradesh".

Acknowledgements: I thank the Director and Dean, Wildlife Institute of India and Madhya Pradesh Forest Department for providing permissions and logistic support. I acknowledge the help rendered by the field assistantsShivanand and Dhanalal during the fieldwork Dr. Asha Rajvanshi, Dr. K. Ramesh, Dr. J. Antony Johnson and Dr. Jatinder Chadha are thanked for their technical guidance and assistance in the preparation of the manuscript.

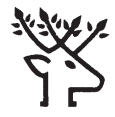
भारतीय वन्यजीव संस्थान Wildlife Institute of India

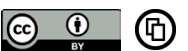

OPEN ACCESS | FREE DOWNLOAD
Abstract: In Hindu mythology, Hanuman is worshipped as the monkey god and therefore there is a great reverence for macaques all across the country. Hindu devotees consider it their sacred duty to feed macaques along road, temples, parks and other public areas. Unfortunately, such food provisioning alters the habitat, food choice and behaviour of macaques. We studied the impact of feeding by humans on Rhesus Macaque Macaca mulatta feeding behaviour, distribution and also assessed the increased risk of accidents in the $11 \mathrm{~km}$ road stretch of National Highway passing through Kanha-Pench corridor, from August 2009 to July 2010. Seasonal changes in macaque distribution and group sizes were assessed based on foot and vehicle transects. The numbers of road kills were monitored in early morning and late evening hours for different seasons. Five groups of macaques were occupying a minimum of 1.1 to a maximum of $1.7 \mathrm{~km}$ stretch, together covering about $7.3 \mathrm{~km}$ of road. Group size varied significantly in relation to the availability of food on the road. During the study, 54 macaques succumbed to road accidents. Maximum roadkill occurred during summer because of the greater inflow of tourists. Unless concerted efforts are made to increase awareness among people of the hazards of road-side feeding, incidences of macaque mortality are likely to increase.

Keywords: Behaviour, feeding, Pench Tiger Reserve, Rhesus Macaques, roadkills.

\section{INTRODUCTION}

India has long been known as one of the rich primate areas of the world, both in species diversity and population abundance. Eight species of macaques occur in India, namely, Rhesus Macaque Macaca mulatta, Bonnet Macaque M. radiata, Assamese Macaque M. assamensis, Stumptailed Macaque M. arctoides, Pig-tailed Macaque M. leonina, Lion-tailed Macaque M. silenus, Arunanchal Macaque M. munzala and Long-tailed Macaque M. fascicularis umbrosa. The Rhesus Macaque Macaca mulatta is one of the most common non-human primates in India. Among the non-human primate species of the world, the Rhesus macaque has the widest geographic distribution, occuring from Afghanistan in the west to Vietnam, Hong Kong and eastern China as far north as Beijing (Bangjie 1985). The Rhesus Macaque is a diurnal species occurring in a variety of habitats occupying both terrestrial and arboreal niches. They inhabit the deserts of Rajasthan, agricultural plains of the Gangetic basin, the tropical forests of southeastern Asia, the temperate pine forests of the Himalaya, and the rugged mountains of north central China (Southwick et al. 1994). In India, Rhesus Macaques are found from $1400 \mathrm{~m}$ altitude in the Himalaya to the sea level in Sunderbans and in the south up to the river Godavari (Srivastava 1999). Range overlap with Bonnet Macaques occurs in the southern part of the country (Fooden et al. 1981). Rhesus 
Macaques are the most adaptable of all non-human primates and have learned to live amidst human habitations. In India, 80 to $90 \%$ of Rhesus Macaques live in close association with human populations, and are therefore highly dependent on people for food (Southwick et al. 1965, 1976).

This relationship between humans and monkeys dates back to ancient cultures and is deeply rooted in Hindu mythology. Monkeys are associated with Hanuman, the Monkey God in the epic Ramayana. Monkeys are believed to be the direct descendants of Lord Hanuman and are highly revered by Hindus. Feeding of monkeys on road sides is still a common practice across India. The increasing number of habituated macaque populations living in proximity to human settlements has become a major concern in India. Southwick et al. (1976) documented in detail the effect of artificial feeding on behaviour and ecology of Rhesus Macaques. The study not only highlighted the changes in the aggressive behaviour associated with artificial feeding but also recorded changes in their diet, home range, and primary habitat that further influenced social behaviour and the spatial distribution of the animals. Several authors have recorded the negative effects of artificial feeding and roadkill studies on Hanuman Langurs Semnopitheaus entellus in India (Mohnot 1974; Agoramoorthy 1987; Rajpurohit 1987; Rajpurohit et al. 1997; Chhangani 2000, 2001, 2004).

Studies are lacking related to impacts of road side feeding by humans on distribution and risks of mortality in Rhesus Macaques in India; this study assesses these impacts.

\section{Study area}

The National Highway NH-7 runs along the northsouth axis connecting Varanasi (northern India) with Nagpur (central India) and Hyderabad and Bengaluru (southern India). This study was conducted in the $11 \mathrm{~km}$ stretch of NH-7 between the villages Kurai $\left(21^{\circ} 49^{\prime} \mathrm{N}\right.$ \& 79 $\left.9^{\circ} 30^{\prime} \mathrm{E}\right)$ in the south to Gandatola $\left(21^{\circ} 53^{\prime} \mathrm{N}\right.$ \& $79^{\circ} 32^{\prime} \mathrm{E}$ ) in the north, aligned along on the eastern boundary of the Pench Tiger Reserve, Madhya Pradesh and bisecting the Kanha-Pench corridor. The portion of the road is routed along the eastern boundary of Pench Mowgli Sanctuary of the Pench Tiger Reserve for a length of $11 \mathrm{~km}$ (Fig. 1). The topography of the study area is mostly undulating, characterized by small

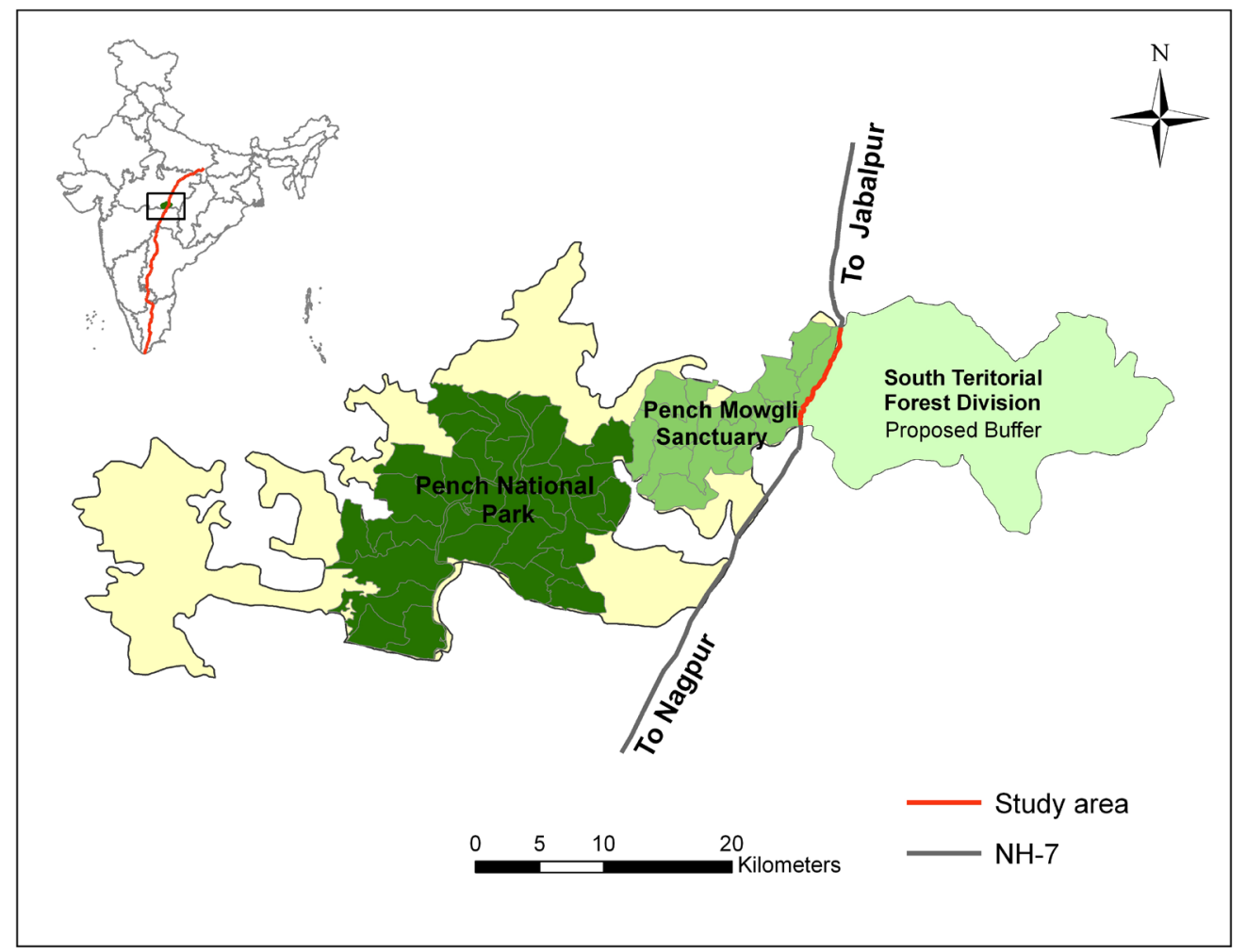

Figure 1. Section of the $\mathrm{NH}-7$ representing the area of the study 
ridges and hills having steep slopes and a number of seasonal streams or nallahs. The mean annual rainfall is around $1400 \mathrm{~mm}$ with the south-west monsoon accounting for most of the rainfall in the region. The temperature varies from a minimum of $0^{\circ} \mathrm{C}$ in winter to $45^{\circ} \mathrm{C}$ in summer.

\section{METHODS}

\section{Distribution of Rhesus Macaques along roads}

Distribution was assessed via two methods: line transects and road transects. A total of 18 permanent line transects ( $2 \mathrm{~km}$ length) were laid perpendicular to the highway over the 11-km stretch in different habitat types on both sides of the road. Each transect was walked four times in a season and information on the number of animals sighted, location, habitat, group size and age structure was collected. Presence of Rhesus Macaques was recorded at every $100 \mathrm{~m}$ on the line transect based on direct evidence. A vehicle was driven along forest roads at a speed of $<20 \mathrm{~km} / \mathrm{h}$ on the transect road. When macaques were spotted, Global Positioning System (GPS; Garmin 72 unit) locations and observations on group size and habitat type were recorded. The same road was surveyed four times in every season. Presence of animals was marked at every $100 \mathrm{~m}$ in GIS domain. In addition, National Highway 7 was also surveyed for macaques on and along the roadside. Encounter rates were calculated for adults and juveniles.

\section{Roadkill data collection}

The sampling period was divided into three seasons: monsoon (July to October), winter (November to February) and summer (March to June). From August
2009 to July 2010 the entire stretch of road $(11 \mathrm{~km})$ was surveyed by vehicle (driven at $10-20 \mathrm{~km} / \mathrm{hr}$ ). Data was recorded twice per day during early morning (0530$0630 \mathrm{hr}$ ) and late evening (1730-1830 hr) for road kills. When kills of Rhesus Macaque were encountered on the road, the team recorded GPS location, determined sex and age and took notes on roadside habitat features. The dead macaques were identified and removed from the road to avoid repeat count in subsequent surveys. We used a kernel density estimation method (Gitman \& Levine 1970) for identifying high mortality zones using the spatial analyst toolbox for ArcGIS following Ramp et al. 2005, 2006 and Gomes et al. 2009. Traffic information was collected by continuous monitoring for three days per season to determine the per day traffic volume during the study period.

\section{RESULTS}

\section{Group size and distribution along road}

In the study area a total of five major groups of macaques identified as A, B, C, D and E were observed in the $11 \mathrm{~km}$ section of road (Table 1, Fig. 3). These groups together comprised 305 animals representing 67 males, 158 females and 80 juveniles. Sometimes a group temporarily broke into smaller groups with varying numbers of individuals. Group size varied between 36 and 82 individuals, with mean $61 \pm 19$. Group size was positively related to the number of people feeding monkeys on the road (Pearson-product moment $r=0.968, p=0.01)($ Table1). During summer and late winter all individuals in the five groups were attracted towards the road because of food offered by humans. The encounter rate of macaques on the line and road transects survey showed that the use of roadside

Table 1. Average number of Rhesus Macaque sighted on NH-7 along Pench Tiger Reserve

\begin{tabular}{|c|c|c|c|c|c|c|}
\hline Group & Male & Female & Juvenile & $\begin{array}{c}\text { Total no. of } \\
\text { individual }\end{array}$ & $\begin{array}{c}\text { Average no. } \\
\text { of feedings by } \\
\text { humans per } \\
\text { day }\end{array}$ & $\begin{array}{c}\text { Length } \\
\text { occupied } \\
\text { in km }\end{array}$ \\
\hline A & 9 & 26 & 10 & 45 & 14 & 1.1 \\
\hline B & 15 & 35 & 17 & 67 & 32 & 1.6 \\
\hline C & 17 & 34 & 24 & 75 & 37 & 1.7 \\
\hline D & 7 & 18 & 11 & 36 & 16 & 1.4 \\
\hline E & 19 & 45 & 18 & 82 & 47 & 1.5 \\
\hline Total & $\mathbf{6 7}$ & $\mathbf{1 5 8}$ & $\mathbf{8 0}$ & $\mathbf{3 0 5}$ & $\mathbf{1 4 6}$ & $\mathbf{7 . 3}$ \\
\hline
\end{tabular}




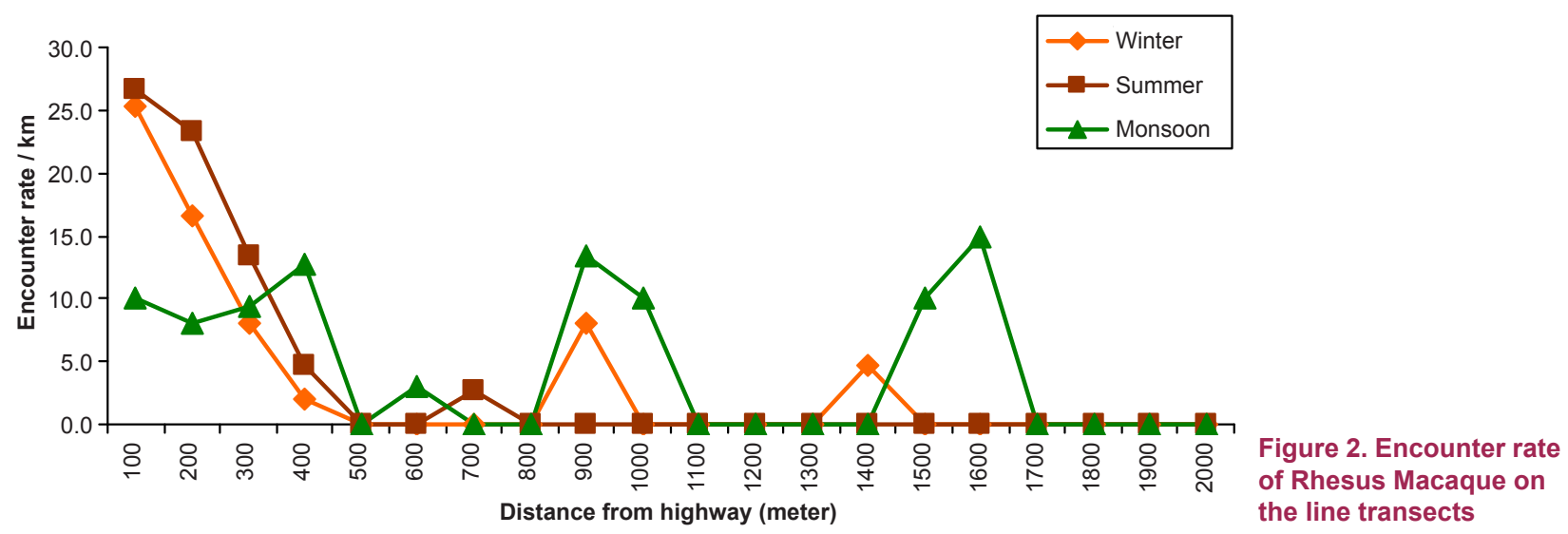

Table 2. Number of Rhesus Macaques killed on the NH-7 along Pench Tiger Reserve

\begin{tabular}{|c|c|c|c|c|}
\hline Group & Male & Female & Juvenile & $\begin{array}{c}\text { Total no. of } \\
\text { individuals }\end{array}$ \\
\hline A & 3 & 2 & 2 & 7 \\
\hline B & 2 & 3 & 0 & 5 \\
\hline C & 4 & 7 & 3 & 14 \\
\hline D & 1 & 6 & 1 & 8 \\
\hline E & 8 & 11 & 1 & 20 \\
\hline Total & $\mathbf{1 8}$ & $\mathbf{2 9}$ & $\mathbf{7}$ & $\mathbf{5 4}$ \\
\hline
\end{tabular}

habitats in summer and winter was relatively high at $26.7 \pm 7.5$ individuals $/ \mathrm{km}$, and gradually decreased towards the forest interior, where no individuals were seen during summer (Fig. 2). The length of the road stretch occupied by different groups varied between 1.1 to $1.7 \mathrm{~km}$ together covering about $7.3 \mathrm{~km}$ length (Table 1).

\section{Roadkills}

During the study period, 54 Rhesus Macaques were found killed on the road. The number of females killed was higher than the number of males and juveniles (Kruskal-Wallis $\chi^{2}=5.70, p=0.05$. (Table 2). The number of road kills was 27, 19 and eight during summer, winter and monsoon respectively. Traffic intensity during summer, winter and monsoon was 3269, 2951 and 2884 vehicles/day respectively. Road kills were positively correlated with vehicular intensity (Spearman's rho $=1.00, \mathrm{p}<0.01$ ). Fatalities of the Rhesus Macaque occurred in a cluster on the road (Fig. 3). The kernel density method clearly revealed that the maximum number of roadkills was taking place at a location where the frequency of

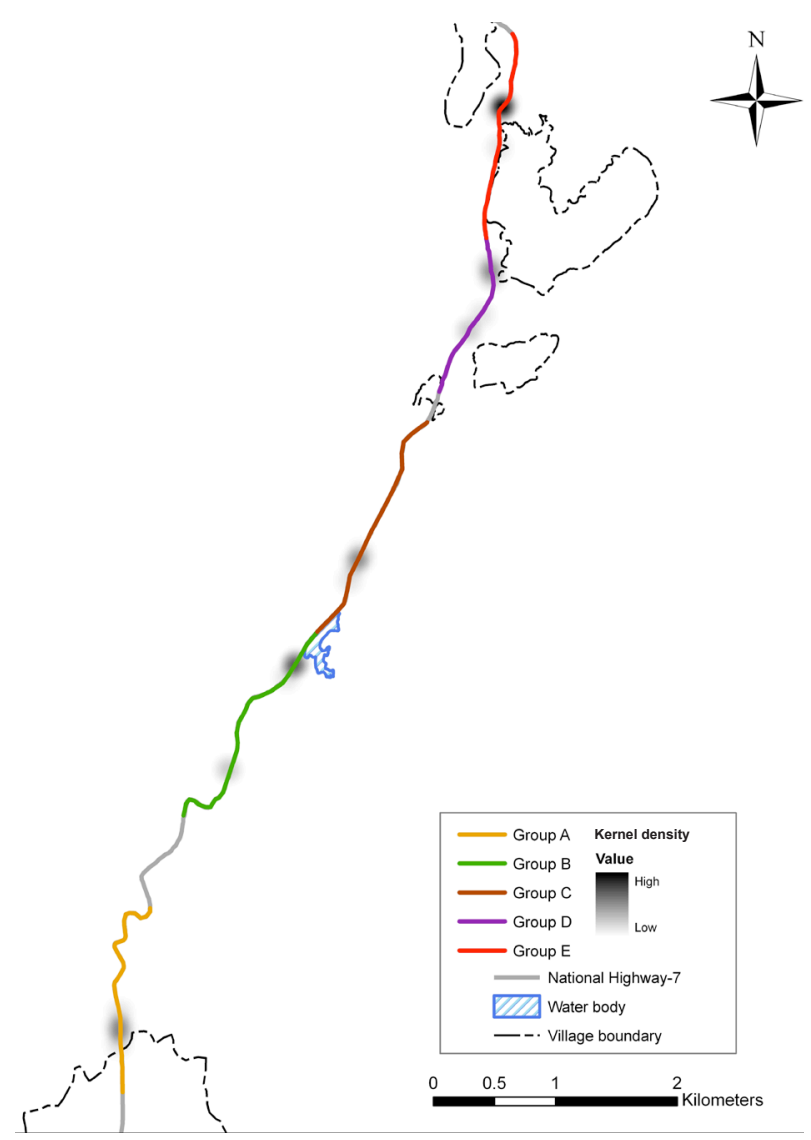

Figure 3. Location of Rhesus Macaque groups and location of road kills

feeding (artificial feeding) by passer-by was high.

\section{DISCUSSION}

Mean group sizes of macaques vary between 9.841 in forest (Southwick et al.1965; Mukherjee \& Gupta 1965; Neville 1968; Singh 1969; Lindburg 1971; 
Makwana 1978), and in urban area, it varies between 10-42 (Southwick et al. 1965; Mukherjee 1972) in urban and semiurban areas. The group size recorded in this study varied between 36- 82 individuals, mean 61 \pm 19 . The higher group size found in the present study may be because of human feeding. The encounter rate of Rhesus Macaque shows the maximum number of animals using the roadside habitat during summer and late winter (Fig. 2). Southwick (1976) observed for 16 years that the Rhesus Macaques were found to use a specific location in all seasons. The study conducted in Asarori Forest in Dehradun by Makwana (1978) shows that foraging area for rhesus macaque was approximately 1.05 to $3.5 \mathrm{~km}$. In this study rhesus macaque foraging area was a minimum of $1.1 \mathrm{~km}$ to a maximum of $1.7 \mathrm{~km}$. The movement of the macaques was restricted by the availability of food from passersby. The five group of macaques covered about $7.3 \mathrm{~km}$ of the total length of the study area (Table 1).

In total 54 Rhesus Macaques were killed on this road (Table 2). This clearly reflects that the Rhesus macaque

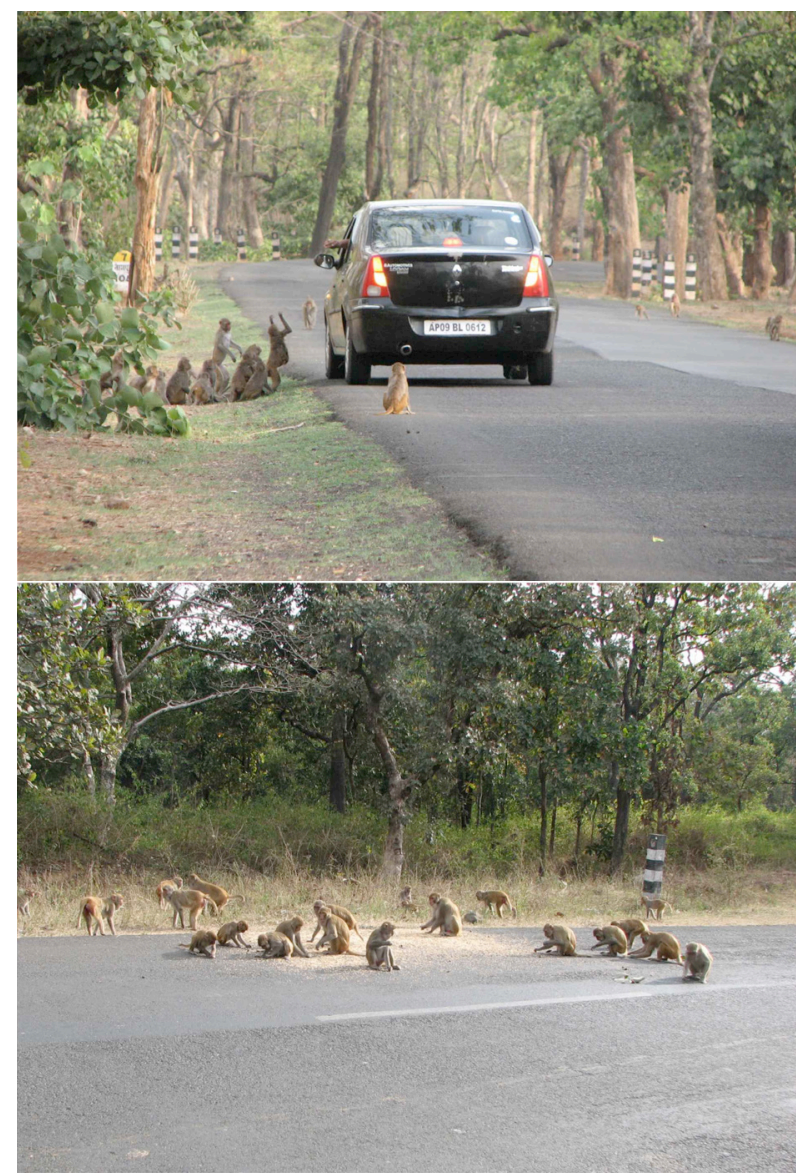

Image 1. Rhesus Macaques being fed by a passer-by. is highly vulnerable to road accidents compared to other animals in the study area. Maximum number of road kills occurred during summer because of large numbers of tourist offering food (Image 1). The study conducted on Hanuman Langur by Chhangani (2004) showed that the maximum number of roadkills occurred during monsoons. Both studies showed that the passer-by behaviour of feeding animals influenced the road kills. The Rhesus Macaque is largely vegetarian but occasionally eats insects (Seth 2001). In earlier days, people used to feed macaques along the road by offering them gram or bananas. These days people offer all sorts of food including biscuits, chips and other snacks which are thrown in the middle of the roadway. Based on discussions with some passers-by and truck drivers, it was learnt that the people have adopted the practice of feeding macaques because they believed that monkeys do not get anything else to feed on. This irregular feeding makes macaques aggressive in their behaviour towards humans and other species (Bernstein \& Mason 1963; Koford 1963; Loy 1970; Southwick et al. 1976). It is a common observation that when vehicles halt, macaques surround them forcing traveler(s) to offer eatables. In retaliation some people pelt stones. This indicates that the artificial feeding of wild macaques alters their habits and behaviour.

Roadkills of a wide array of wild animals are one of the major challenges in the current conservation scenario. Forest department and other non-government organizations are creating awareness amongst people by putting up hoardings along roadsides to educate people about the implications of feeding animals on the road (Image 2). These messages are generally ignored by people who continue to feed macaques because of the religious sentiments attached to this species. The monkey menace will only continue to grow unabated posing greater risks of road accidents, increasing human-wildlife conflicts and rising trends in mortality of macaques eventually leading to decline in their populations in the long term. Concerted efforts are needed by the conservation community, the state forest departments and civil society in raising awareness about the threats associated with artificial feeding of macaques. 

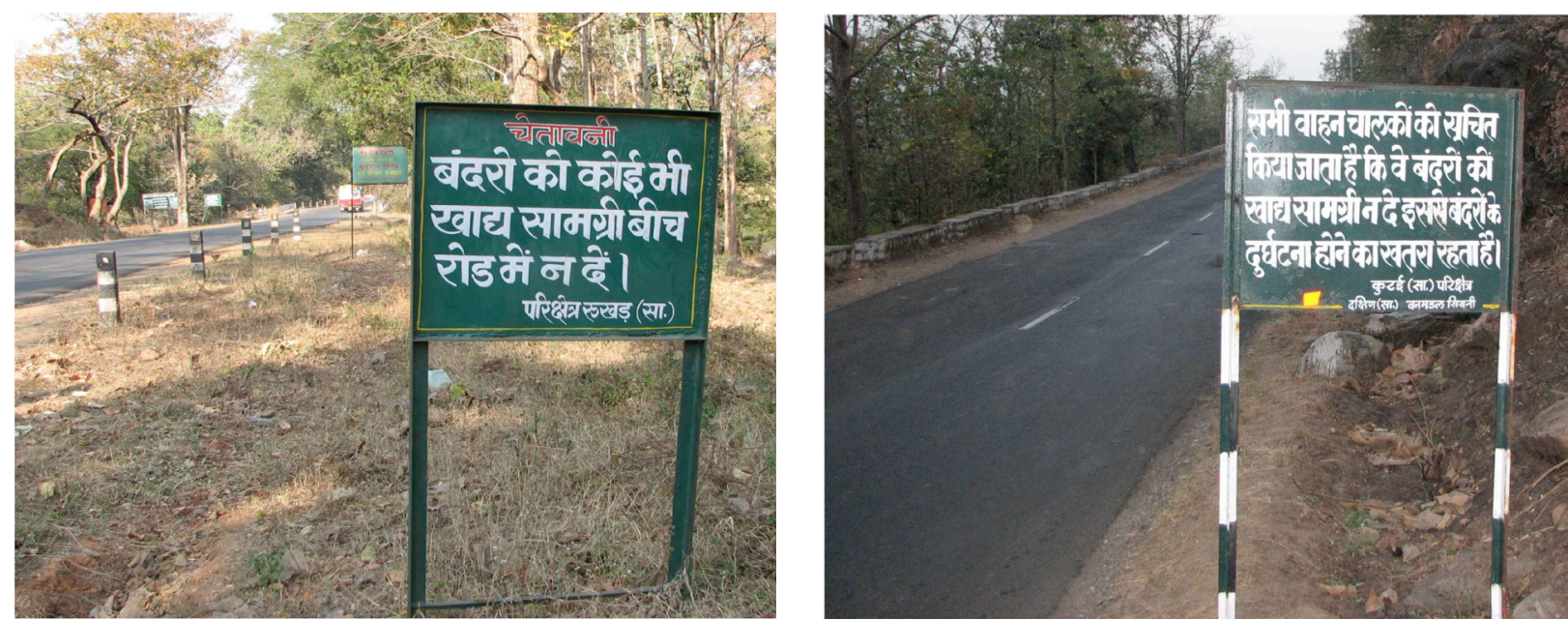

Image 2. Hoardings put up by the state forest department for creating awareness about hazards of feeding monkeys

\section{REFERENCE}

Agoramoorthy, G.(1987). Reproductive behaviour in Hanuman Langur, Presbytis entellus. $\mathrm{PhD}$ Thesis. University of Jodhpur, Jodhpur.

Bangjie, T. (1985). The status of primates in china. Primate Conservation 5: 63-81.

Bernstein, I. \& W.A. Mason (1963). Activity patterns of rhesus monkeys in a social group. Animal Behaviour 11: $455-460$.

Chhangani, A.K. (2000). Ecobehavioral diversity of langurs, Presbytis entellus living in different ecosystems. $\mathrm{PhD}$ Thesis. JNV University of Jodhpur, Jodhpur.

Chhangani, A.K. (2001). Threats to Kumbhalgarh Wildlife Sanctuary in relation to flora and fauna. Journal of Nature Conservation 13(2): 177-185.

Chhangani, A.K. (2004). Killing of Hanuman Langur in road accidents in Knumbhalgarh Wildlife Sanctuary, Rajasthan, India. Primate Report 69.

Fooden, J., A. Mahabal \& S.S. Saha (1981). Redefinition of the Rhesus Macaques-Bonnet Macaque boundary in peninsular India. Journal of the Bombay Natural History Society 78: 463-474.

Gitman, I., Levine, M.D. (1970). An algorithm for detecting unimodal fuzzy sets and its application as a clustering technique. IEEE Transactions on Computers 19: 583-593.

Gomes, L., C. Grilo, C. Silva \& A. Mira (2009). Identification methods and deterministic factors of owl road kill hotspot locations in Mediterranean landscapes. Ecological Research 24: $355-370$.

Koford, C. (1963). Group relations in an island colony of Rhesus Monkeys, pp. 136-152. In: Southwick, C.H. (ed.). Primate Social Behavior. D. Van Nostrand Co., New York.

Lindburg, D.G. (1971). The Rhesus Monkey in north India: An ecological and behavioural study, pp. 1-106. In: Rosenblum, L.A. (ed.). Primate Behaviour; Developments in Field and Laboratory Research, Vol. 2. Academic Press, New York.
Loy, J. (1970). Behavioral response of free-ranging rhesus monkeys to food shortage. American Journal of Physical Anthropology 33: 263-271.

Makwana, S.C. (1978). Field ecology and behaviour of the Rhesus Macaque (Macaca mulatta): I. group composition, home range, roosting sites, and foraging routes in the Asarori forest. Primates 19(3): 483-492.

Mohnot, S.M. (1974). Ecology and behaviour of the common Indian langur, Presbytis entellus. PhD Thesis. University of Jodhpur, Jodhpur.

Mukherjee,A.K.\& S. Gupta (1965). Habits of rhesus macaque, Macaca mulatta in the Sunderbans, West Bengal. Journal of the Bombay Natural History Society 62: 145-146.

Mukherjee (1972). Group composition and population density of Rhesus Monkey, Macaca mulatta in northern India. Primates 13: 65-70.

Neville, M.K. (1968). Ecology and activity of the Himalayan foot-hill Rhesus Monkeys (Macaca mulatta). Ecology 40: 110-123.

Rajpurohit, L.S. \& A.K. Chhangani (1997). Males' number decreasing in langurs (Presbytis entellus) around Jodhpur . Abstracts - 1st Goettinger Freilandtage on Primate SocioEcology: Causes and Consequences of Variation in the Members of Males Per Group, German Primate Centre (DPZ), Gottingen (Germany). Primate Report 48(2): 30.

Rajpurohit, L.S. (1987). Male social organization in Hanuman Langur (Presbytis entellus). PhD Thesis. University of Jodhpur, Jodhpur.

Ramp, D., J. Caldwell, A.E. Kathryn, D. Warton \& D.B. Croft (2005). Modeling of wildlife fatality hotspots along the Snowy Mountain Highway in New South Wales, Australia. Biological Conservation 126: 474-490.

Ramp, D., V.K. Wilson \& D.B. Croft (2006). Assessing the impact of roads in peri-urban reserves: Road-based fatalities and road usage by wildlife in the Royal National Park, New South Wales, Australia. Biological Conservation 129: 348-359. 
Seth, P.K., P.K. Chopra \& S. Seth (2001). Indian Rhesus Macaque: habitat, ecology and activity patterns of naturally occurring populations. In: Gupta, A.K. (ed.) ENVIS Bulletin: Wildlife \& Protected Areas, Non-Human Primates of India 1(1): 68-80.

Singh, S.D. (1969). Urban monkeys. Scientific American 221: 108-115.

Southwick, C.H., M.A. Beg \& M.R. Siddiqi (1965). Rhesus Monkeys in north India, pp. 111-159. In: DeVore, I. (ed.) Primate Behavior: Field Studies of Monkeys and Apes. New York.
Southwick, C.H. \& M.F. Siddiqi (1994). Population status of primates in Asia, with emphasis on Rhesus Macaques in India. American Journal of Primatology 34: 51-59.

Southwick, C.H., M.F. Sidiqi, M.Y. Farooqui \& B.C. Pal (1976). Effects of artificial feeding on aggressive behaviour of rhesus monkeys in India. Animal Behavior 24(1): 1115 .

Srivastava, A. (1999). Rhesus Macaque, pp. 141-145. In: Primates of Northeast India. Mega Diversity Press, India. 